\title{
Effects of aerobic exercise of different intensities in the liver of metabolic syndrome animals
}

\author{
SOUSA, L. A. C. ${ }^{1}$, SAUCEDO, S. C. M. ${ }^{1}$, VELOSO, A. G. B. ${ }^{1}$, MACHI, J. F. ${ }^{2}$, \\ WICHI, R. B. ${ }^{3}$, ORNELAS, E. M. ${ }^{1}$ and MAIFRINO, L. B. M. ${ }^{1,4 *}$ \\ ${ }^{1}$ Laboratório de Estudos Morfoquantitativo e Imunohistoquímico - LEMI, Universidade São Judas Tadeu - USJT, \\ Rua Taquari, 546, CEP 03166-000, São Paulo, SP, Brazil \\ ${ }^{2}$ Unidade de Hipertensão, Instituto do Coração - InCor, Universidade de São Paulo - USP, Avenida Dr. Enéas de \\ Carvalho Aguiar, 44, Pinheiros, CEP 05403-900, São Paulo, SP, Brazil \\ ${ }^{3}$ Departamento de Educação Física, Faculdade Federal de Sergipe, Rua Cláudio Batista, s/n, Cidade Nova, \\ CEP 49060-108, Aracajú, SE, Brazil \\ ${ }^{4}$ Instituto de Cardiologia Dante Pazzaneze - IDPC, Avenida Dante Pazzanese, 500, CEP 04012-180, São Paulo, \\ SP, Brazil \\ *E-mail: lmaifrino@uol.com.br
}

\begin{abstract}
Introduction: Metabolic syndrome (MS) corresponds to a sum of alteration in which, glucose intolerance is characterized as one of the most important. Among these are included: insulin resistance, type 2 diabetes mellitus, hypertension, obesity, dyslipidemia, endothelial dysfunction and others Nonalcoholic steatohepatitis (NASH) is also currently cited as a risk factor for MS Studies have demonstrated a strong correlation between physical inactivity and MS. The aim of this paper was to evaluate the effects of aerobic exercise training of different intensities on the liver of metabolic syndrome rats. Methods: 20 male Wistar rats were used and divided into four groups ( $\mathrm{n}=5$ ): control (C) sedentary MS (MS), walking MS (WMS) and running MS (RMS). Fructose-drinking rats received D-fructose $(100 \mathrm{~g} / \mathrm{l})$. MS Training rats were assigned to a treadmill training protocol at low and moderate intensity during $1 \mathrm{~h} /$ day, 5 days/week for 8 weeks. At the end of the experiment, the livers were collected and submitted to a histological technique (HE). The images were captured and morphometric and stereological analysis of the hepatic tissue were performed. Results: It was verified that MS promoted a hypertrophy of the hepatocytes, a significant increase in the density volume of the hepatocytes, of the Kupffer cells, and hepatic sinusoids, and that, in both intensities (Running and Walking) the exercise training has mitigated the alterations. Conclusions: The data suggest, as nonpharmacological treatment, the walking (low intensity) is the most efficient, able to reverse the alterations caused by metabolic syndrome, the results being approximate to those of control group.
\end{abstract}

Keywords: liver, exercise, fructose, morphometry.

\section{Introduction}

The metabolic syndrome is a complex and frequently occurring disorder since it involves a variety of pathological factors, such as Diabetes Mellitus, which is already considered by the World Health Organization an epidemic disease. The multiplicity of this syndrome is characterized by risk factors as hypertension, insulin resistance, hyperinsulinemia, glucose intolerance/diabetes type 2, central obesity and dyslipidemia, and most recently the nonalcoholic steatohepatitis (NASH), which may favor the occurrence of cardiovascular diseases (IGLSEDER, CIP, MALAIMARE et al., 2005; ECKEL, GRUNDY and ZIMMET, 2005; DESPRES and LEMIEUX, 2006; HANLEY, WILLIAMS, FESTA et al., 2005).

Several studies show the correlation between the fructose and lipid consumptions and the appearance of metabolic syndrome markers (BRAY, NIELSEN and POPKIN, 2004; HANLEY, WILLIAMS, FESTA et al., 2005; MILLER and ADELI, 2008).

Sugar-rich diets, specially fructose, contribute to the chronic metabolic imbalance which the fundamental pathophysiological element is the insulin resistance that promotes the increase the lipid deposition in the liver, contributing to the increase of reactive of oxygen species (ROS) and causing hyper lipid peroxidation, and an increase of stellate cells activation, abnormal cytokines production, resulting damage to the cell and fibrosis, (ANGULO, 2002) leading to nonalcoholic fatty liver disease (NAFLD) (PETTINELLI, OBREGÓN and VIDELA, 2011; MINCIS and MINCIS, 2006).

NAFLD refers to a spectrum of diseases ranging from a simple hepatic steatosis to more severe manifestations including nonalcoholic steatohepatitis (NASH) which may progress to fibrosis, cirrhosis, and liver failure (MULHALL, ONG and YOUNOSSI, 2002; ANGULO, 2002). Marchesini, Bugianesi, Forlani et al. (2003) report that the presence of the metabolic syndrome increases the risk of NASH among the nonalcoholic fatty liver diseases.

Several studies indicate that physically active individuals enjoy a better quality of life and lower mortality rate, resulting in higher longevity (ANTUNES, SANTOS, CASSILHAS et al., 
2006). Several research linking MS to exercise, have shown significant results by reducing insulin resistance and minimizing the morphological changes in key organs, such as, heart, aorta and pancreas (CIOLAC and GUIMARÃES, 2004; MORVAN, LIMA, MARCHI et al., 2013; AMARAL, LIMA, ORNELAS et al., 2015).

Thus, regular physical exercise as a nonpharmacological treatment may be a strategy aimed at preventing and reducing several risk factors, as diabetes mellitus blood pressure, dyslipidemia, and nonalcoholic steatohepatitis.

\section{Materials and Methods}

Experiments were performed 20 young male Wistar rats (110-120g) from the Animal House of the São Judas Tadeu University, São Paulo, Brazil. The animals were housed in collective polycarbonate cages in a temperature-controlled room $\left(22^{\circ} \mathrm{C}\right)$ with a $12 \mathrm{~h}$ dark-light cycle (light 07:0019:00h). Rats were fed standard laboratory chow.

The experimental protocol was approved by the institutional animal care and use committee of the São Judas Tadeu University (Protocol 063/2006), and this investigation was conducted in accordance with the Principles of Laboratory Animal Care formulated by the National Institutes of Health (National Institutes of Health Publication No., 96-23, Revised 1996). The animals were divided into four groups $(\mathrm{n}=5)$ : control (C), sedentary metabolic syndrome (MS), walking metabolic syndrome (WMS) and running metabolic syndrome (RMS).

The methods were applied in different stages:

\subsection{Induced metabolic syndrome}

metabolic syndrome was induced via fructose overload in the drinking water (D-fructose, $100 \mathrm{~g} / \mathrm{l}$ ) for 18 weeks (SUZUKI, NOMURA, ODAKA et al., 1997). Control animals received only water during this period. Animals weighing was performed once a week during the whole period of the protocol.

\subsection{Exercise training experimental protocol}

After 9 weeks of induced metabolic syndrome, the animals were adapted to the treadmill $(10 \mathrm{~min} /$ day; $0,3 \mathrm{~km} / \mathrm{h})$. All groups were submitted to a maximal treadmill exercise test to determine aerobic capacity and the initial and final ET intensities. From the maximal treadmill exercise training were then prescribed a moderate intensity $(50-60 \%$ of maximal running speed) and low intensity (20-30\% of maximal running speed) trainings for one hour/day, 5 days/week, to the WMS and RMS animals (DE ANGELIS, D'AVILA, GADONSKI et al., 1999).

\subsection{Euthanasia of the animals}

At the end of the experiment, the animals were euthanized by decapitation and blood samples were collected. Afterwards, the abdominal cavity was opened and the liver removed, weighed, sectioned and fixed in formaldehyde solution, 10\% in phosphate buffer for 24 hours. After this procedure, the pieces were dehydrated, diaphanized and embedded in paraffin. $5 \mu \mathrm{m}$ thick non serial cuts of sections were performed in the microtome (LUPE) and mounted on glass slides. Each slide had a total of six sections stained using Haematoxylin-Eosin method.

\subsection{Morphoquantitative analysis}

The images were captured using a system consisting of a Sony micro camera connected to Zeiss Microscope that receives the images of histological slices and transmits them to a Pentium IV CPU equipped with specific software (Axio Vision 4.8, Zeiss) for micro-quantitative analysis.

Morphometric and stereological analysis were performed in 20 micrographs per animal, totaling 100/group with a magnification of $\times 100$. The morphometric analysis was performed using the Axio Vision computer program to determine the larger area of the hepatocytes, and for the stereological analysis was applied a test-system with 374 points in order to quantify the following parameters: volume density of nuclei and cytoplasm of the hepatocytes, Kupffer cells, sinusoids and hepatic vessels and ducts (MANDARIM-DE-LACERDA, 2003). For this analysis were used the Image J (version 1.47 - National Institutes of Health) where the points that hit the analyzed structures were counted.

The obtained data were tabulated and the standard errors of the means were calculated. The four groups were statistically compared by the ANOVA two-way and Kruskal - Wallis test $(\mathrm{p}<0.05)$.

\section{Results}

\subsection{Histopathological of the liver}

The Control group presents polygonal hepatocytes forming expanse anastomosing plates with one or two large, central, rounded nuclei, heavily stained using haematoxylin, and in some of them, one or more nucleolus may be found. Among the hepatocytes plates, we verify a large number of hepatic sinusoidal capillaries in which the walls present Kupffer cells added with its enlarged and/or triangular and heavily stained nuclei (Figure 1A).

The metabolic syndrome group evidences alterations in the liver tissue caused by MS. Hepatocytes and its nuclei are hypertrophied, presenting a more acidophilus cytoplasm a large quantity of Kupffer cells nuclei showing little evidence of sinusoids. (Figure 1B) In the trained groups, it is observed that the animals that performed a low-intensity ET (WMS) present more hypertrophied hepatocytes, evident nucleolus and vacuolization (intercellular spaces). In this group, the lumen of sinusoidal capillaries is full of erythrocytes. (Figure 1C) In the RMS, hepatocytes show smaller nucleus and cytoplasm compared to those found in WMS. The nucleus of these cells is increased and the cytoplasm shows higher acidophilia. (Figure 1D). Reduced vacuolization (intercellular spaces) is observed compared to what was showed in the WMS. (Figure 1D).

\subsection{Area and diameter of hepatocytes}

Analyzing the area and the diameter of hepatocytes, we verified that metabolic syndrome promoted a hypertrophy of the hepatocytes characterized by a significant increase in both area and the long diameter of hepatocytes when compared to control group, and the moderate-intensity training (RMS) promoted a decrease in both parameters compared with the low-intensity training (WMS) (Table 1$)$. 

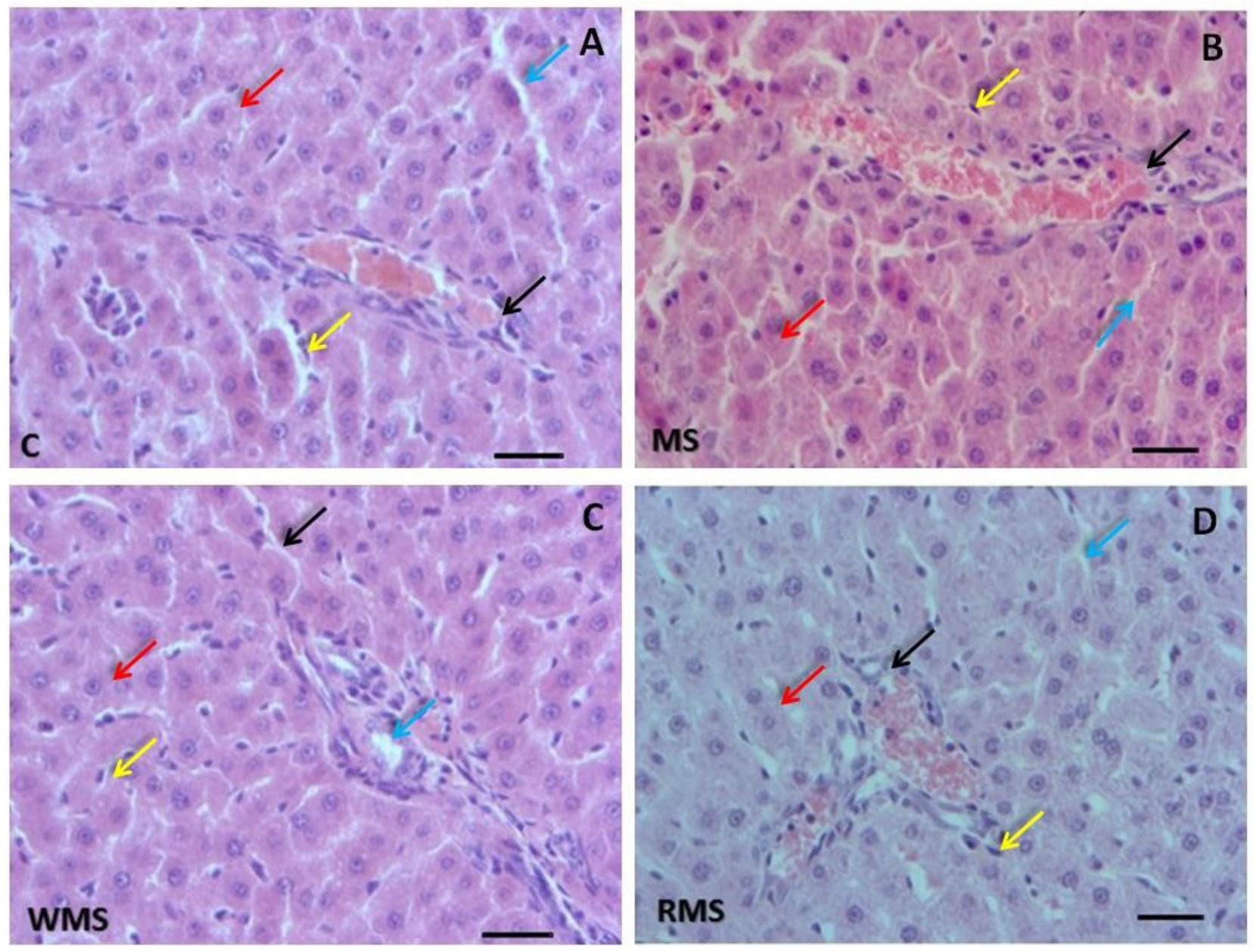

Figure 1. Photomicrographs of the hepatic parenchyma in the studied groups. A. control (C), B.sedentary metabolic syndrome (MS), C. Walking metabolic syndrome (WMS) and D. running metabolic syndrome (RMS). Hepatocytes (red arrow), Kupffer cells (yellow arrow), Sinusoids (blue arrow) and Vessels and Ducts (black arrow) HE. $\times 400$. BAR $-50 \mu m$.

Table 1. Area and diameter of hepatocytes of studied animals.

\begin{tabular}{cll}
\hline $\begin{array}{c}\text { Groups } \\
\text { Parameter }\end{array}$ & Area $\left({\left.\mu \mathrm{m}^{2}\right)}^{2}\right.$ & Diameter $\left(\boldsymbol{\mu m}^{2}\right)$ \\
\hline $\mathrm{C}$ & $217.47 \pm 1.90$ & $18.84 \pm 0.12$ \\
$\mathrm{MS}$ & $266.65 \pm 1.98^{*}$ & $21.54 \pm 0.11^{*}$ \\
WMS & $278.18 \pm 2.30^{* \#}$ & $21.65 \pm 0.12^{*}$ \\
RMS & $258.33 \pm 1.88^{* \#+}$ & $20.76 \pm 0.10^{* \#+}$ \\
\hline $\mathrm{M} \pm$ SEM: ${ }^{*} p<0,05$ vs $\mathrm{C} ;{ }^{*} p<0,05 \mathrm{vs} \mathrm{MS} ;{ }^{+} p<0.05$ vs WMS.
\end{tabular}

\subsection{Volume density of hepatic cells in the lobular parenchyma}

Results related to the volume density are presented in Table 2. When analyzing the volume density of hepatic cells in the lobular parenchyma of Syndrome Metabolic animals (MS), we observe an increase in the area occupied by the nuclei $(24.95 \pm 0.38)$ and cytoplasm $(57.84 \pm 0.94)$ totaling $82,93 \%$ of in the test area, considered significant compared to Control group $(69,89 \%)$ The low-intensity training $(74.73 \pm 4.85)$ showed a tendency for reversing the process, not occurring the same with the moderate intensity group $(86.38 \pm 4.96)$ (Table 2).

\subsection{Volume density of parenchyma: Kupffer Cells}

The metabolic syndrome caused a significant increase in the volume density of the Kupffer cells when compared to control animals and the training proved more efficient in both intensities (Table 2).

\subsection{Volume density of sinusoids, ducts and vessels in the parenchyma}

It was observed that metabolic syndrome (MS) promoted a significant reduction in the volume density of sinusoids $(4.36 \pm 0.35)$ and an increase in the vessels and ducts $(2.83 \pm 0.27)$ when compared to the Control group $(21.07 \pm 1)$ and $(1.05 \pm 0.32)$ respectively. We verified that Walking showed more efficiency in reversing the process, which was not seen in the running (Table 2).

\section{Discussion}

It is known that fructose-rich diet affects the metabolism of carbohydrates and lipids (KELLEY, ALLAN and AZHAR, 2004 ) inducing glucose intolerance, diabetes mellitus type 2, hypertension, obesity and metabolic syndrome (ELLIOTT, KEIM, STERN et al., 2002; BRAY, NIELSEN and POPKIN, 2004; MILLER and ADELI, 2008). 
Table 2. Volume density values of hepatocytes nucleus and cytoplasm, Kupffer cells, sinusoids, ducts and vessels (percentage) of hepatic tissue in studied animals.

\begin{tabular}{ccccc}
\hline Parameter/Groups & C & MS & WMS & RMS \\
\hline Nucleus (\%) & $17.70 \pm 0.82$ & $24.95 \pm 0.38^{*}$ & $23.27 \pm 0.73^{*}$ & $19.59_{ \pm 0.29^{\#+}}$ \\
Cytoplasm (\%) & $52.27 \pm 0.75$ & $57.84 \pm 0.94^{*}$ & $51.46 \pm 1^{\#}$ & $66.79 \pm 0.89^{* \#+}$ \\
Hepatocytes (\%) & $69.89 \pm 5$ & $82.93 \pm 5.18$ & $74.73 \pm 4.85^{* \#}$ & $86.38 \pm 4.96^{*+}$ \\
Kupffer cells (\%) & $7.91 \pm 0.46$ & $10.04 \pm 0.71^{*}$ & $8.97 \pm 0.51$ & $7.28 \pm 0.55^{\#}$ \\
Sinusoids (\%) & $21,07 \pm 1$ & $4.36 \pm 0.35^{*}$ & $15.28 \pm 0.6^{* \#}$ & $3.58 \pm 0.25^{*+}$ \\
Vessels and ducts (\%) & $1.05 \pm 0.32$ & $2.83 \pm 0.27^{*}$ & $1.01 \pm 0.35^{* \#}$ & $2.79 \pm 0.35^{*+}$ \\
\hline
\end{tabular}

$\mathrm{M} \pm \mathrm{SEM}:{ }^{*} p<0,05$ vs $\mathrm{C} ;{ }^{*} p<0,05$ vs MS; ${ }^{+} p<0.05$ vs WMS.

The MS model induced by high-fructose intake in rats leads to insulin resistance with a very similar metabolic profile of the syndrome observed in humans (DAI and MCNEILL, 1995; MORVAN, LIMA, MACHI et al., 2013).

Exercise training is considered a hypotensive agent in humans and animals (BRUM, SILVA, MOREIRA et al., 2000; KOKKINOS, NARAYAN and PAPADEMETRIOU, 2001) reducing damages in heart and aorta (MORVAN, LIMA, MACHI et al., 2013) in the pancreas (AMARAL, LIMA, ORNELAS et al., 2015), caused by metabolic syndrome. When Johnson, Sachinwalla, Walton et al. (2009) studied the effects of exercise in the liver of obese individuals, he had observed a decrease in the hepatic steatosis degree, helping to reduce the weight and plasma triglycerides concentration.

The present study aimed to evaluate, through morphoquantitative analysis, the effects of aerobic exercise in different intensities (low and moderate) in the hepatic tissue of metabolic syndrome animals. The confirmation of the metabolic syndrome on the studied model was already published by our group (MORVAN, LIMA, MACHI et al., 2013).

In the MS animals, the hepatocytes hypertrophy was noticeable, particularly in the nuclei. This phenomenon may be explained since it is known that fructose produces energy increasing the citrate levels in the hepatocytes mitochondria. These then increase its energy production based on stored TG contributing to insulin resistance in the liver. Furthermore, the growth of lipid oxidation increases the beta-oxidation, which is a potent ROS (reactive oxygen species) producer, increasing the oxidative stress of the liver.

The increased oxidative stress generates an inflammatory process that in long-term, culminates in the hepatocyte apoptosis and liver necrosis which corroborates with the results of this experiment, such as hypertrophy of hepatocytes, Kupffer cells, sinusoids and hepatic increase (BASCIANO, FEDERICO and ADELI, 2005; BOTEZELLI, MOURA, ROSSI et al., 2010).

The analysis of the animals that performed exercises in different intensities shows significant reduction of hepatocytes hypertrophy. The low-intensity group being the most proximate to the Control group. It is explained due the different intensities demand of the hepatocytes a higher and lower energy production through the mitochondria (CIOLAC and GUIMARÃES, 2004), when compared to the MS group.

The low-intensity exercise training differently from the moderate one promotes the reduction of the numbers of the Kupffer cells indicating a decrease of the inflammatory state generated by the SM, and a significant growth of sinusoidal capillaries showing a remodeling process by the rise of the blood flow velocity, by the nitric oxide-dependent and endothelial-dependent extensions, leading to modifications in the vessels as well to better vascular resistance (HORTA, CARVALHO and MANDARIM-DE-LACERDA, 2005).

The recent literature indicates that the excessive intake of fructose is associated with alterations in the glucose and hepatic lipid metabolisms which lead to steatosis and to insulin resistance. However, physical exercise has been considered a powerful weapon to the metabolic syndrome treatment, since, as proved, it enhances the glucose tolerance and reduces the insulin resistance.

From what this study sowed, it may be suggested that low-intensity aerobic exercise (walking), is more efficient, reversing the alterations occurred in metabolic syndrome animals.

\section{References}

AMARAL, F., LIMA, NE., ORNELAS, E., SIMARDI, L., FONSECA, FLA. and MAIFRINO, LBM. Effect of different exercise intensities on the pancreas of animals with metabolic syndrome. Diabetes, Metabolic Syndrome and Obesity, 2015, vol. 8, p. 115-120. PMid:25709484.

ANGELIS, L., D’AVILA, K., GADONSKI, G., FANG, J., DALL'AGO, P., ALBUQUERQUE, VL., PEIXOTO, LRA. and IRIGOYEN, MC. Exercise reverses peripheral insulin resistance in trained L-NAMEhypertensive rats. Hypertension, 1999, v. 34, n. 4, Pt. 2, p. 768-772.

ANGULO, P. Nonalcoholic fatty liver disease. The New England Journal of Medicine, 2002, vol. 346, n. 16, p. 1221-1231. http:// dx.doi.org/10.1056/NEJMra011775. PMid:11961152.

ANTUNES, HK., SANTOS, RF., CASSILHAS, R., SANTOS, RV., BUENO, OF. and MELLO, MTD. Exercício físico e função cognitiva: uma revisão. Revista Brasileira de Medicina do Esporte, 2006, vol. 12, n. 2, p. 108-114. http://dx.doi.org/10.1590/S151786922006000200011 .

BASCIANO, H., FEDERICO, L. and ADELI, K. Fructose, insulin resistance, and metabolic dyslipidemia. Nutrition \& metabolism, 2005, vol. 2, n. 1, p. 1. http://dx.doi.org/10.1186/1743-70752-5. PMid:15723702.

BOTEZELLI, JD., MOURA, RF., ROSSI, CDA., DALIA, RA., CAMBRI, LT., MELLO, MAR. Consumo de frutose e exercício físico, impacto na síndrome metabólica. Motriz: Revista de Educação Física, 2010, vol. 16, n. 1, p. 231-239.

BRAY, GA., NIELSEN, SJ. and POPKIN, BM. Consumption of high-fructose corn syrup in beverages may play a role in the epidemic of obesity. The American Journal of Clinical Nutrition, 2004, vol. 79, n. 4, p. 537-543. PMid:15051594.

BRUM, PC., SILVA, GJJ., MOREIRA, ED., IDA, F., NEGRAO, CE. and KRIEGER, EM. Exercise training increases baroreceptor gain sensitivity in normal and hypertensive rats. Hypertension, 2000, vol. 36, n. 6, p. 1018-1022. http://dx.doi.org/10.1161/01. HYP.36.6.1018. PMid:11116118. 
CIOLAC, EG. and GUIMARÃES, GV. Exercício físico e síndrome metabólica. Revista Brasileira de Medicina do Esporte, 2004, vol. 10, n. 4, p. 319-324.

DAI, S. and MCNEILL, JH. Fructose-induced hypertension in rats is concentration-and duration-dependent. Journal of Pharmacological and Toxicological Methods, 1995, vol. 33, n. 2, p. 101-107. http:// dx.doi.org/10.1016/1056-8719(94)00063-A. PMid:7766916.

DESPRÉS, JP. and LEMIEUX, I. Abdominal obesity and metabolic syndrome. Nature, 2006, vol. 444, n. 7121, p. 881-887. http:// dx.doi.org/10.1038/nature05488. PMid:17167477.

ECKEL, RH., GRUNDY, SM. and ZIMMET, PZ. The metabolic syndrome. Lancet, 2005, vol. 365, n. 9468, p. 1415-1428. http:// dx.doi.org/10.1016/S0140-6736(05)66378-7. PMid:15836891.

ELLIOTT, SS., KEIM, NL., STERN, JS., TEFF, K. and HAVEL, PJ. Fructose, weight gain, and the insulin resistance syndrome. The American Journal of Clinical Nutrition, 2002, vol. 76, n. 5, p. 911 922. PMid:12399260.

HANLEY, AJ., WILLIAMS, K., FESTA, A., WAGENKNECHT, LE., D'AGOSTINO JUNIOR, RB Jr. and HAFFNER, SM. Liver markers and development of the metabolic syndrome: the Insulin resistance atherosclerosis study. Diabetes, 2005, vol. 54, n. 11, p. 3140-3147. http://dx.doi.org/10.2337/diabetes.54.11.3140. PMid:16249437.

HORTA, PP., CARVALHO, JJ. and MANDARIM-DE-LACERDA, CA. Exercise training attenuates blood pressure elevation and adverse remodeling in the aorta of spontaneously hypertensive rats. Life Sciences, 2005, vol. 77, n. 26, p. 3336-3343. http://dx.doi.org/10.1016/j. lfs.2005.05.044. PMid:15964024.

IGLSEDER, B., CIP, P., MALAIMARE, L., LADURNER, G. and PAULWEBER, B. The metabolic syndrome is a stronger risk factor for early carotid atherosclerosis in women than in men. Stroke, 2005, vol. 36, n. 6, p. 1212-1217. http://dx.doi.org/10.1161/01. STR.0000166196.31227.91. PMid:15890992

JOHNSON, NA., SACHINWALLA, T., WALTON, DW., SMITH, K., ARMSTRONG, A., THOMPSON, MW. and GEORGE, J. Aerobic exercise training reduces hepatic and visceral lipids in obese individuals without weight loss. Hepatology (Baltimore, Md.), 2009, vol. 50, n. 4, p. 1105-1112. http://dx.doi.org/10.1002/hep.23129. PMid:19637289.

KELLEY, GL., ALLAN, G. and AZHAR, S. High dietary fructose induces a hepatic stress response resulting in cholesterol and lipid dysregulation. Endocrinology, 2004, vol. 145, n. 2, p. 548-555. http:// dx.doi.org/10.1210/en.2003-1167. PMid:14576175.
KOKKINOS, PF., NARAYAN, P. and PAPADEMETRIOU, V. Exercise as hypertension therapy. Cardiology Clinics, 2001, vol. 19, n. 3, p. 507-516. http://dx.doi.org/10.1016/S0733-8651(05)70232-0. PMid:11570120.

MANDARIM-DE-LACERDA, CA. Stereological tools in biomedical research. Anais da Academia Brasileira de Ciencias, 2003, vol. 75, n. 4, p. 469-486. http://dx.doi.org/10.1590/S0001-37652003000400006. PMid:14605681.

MARCHESINI, G., BUGIANESI, E., FORLANI, G., CERRELLI, F., LENZI, M., MANINI, R. and RIZZETTO, M. Nonalcoholic fatty liver, steatohepatitis, and the metabolic syndrome. Hepatology (Baltimore, Md.), 2003, vol. 37, n. 4, p. 917-923. http://dx.doi. org/10.1053/jhep.2003.50161. PMid:12668987.

MILLER, A. and ADELI, K. Dietary fructose and the metabolic syndrome. Current Opinion in Gastroenterology, 2008, vol. 24, n. 2, p. 204-209. http://dx.doi.org/10.1097/MOG.0b013e3282f3f4c4. PMid:18301272.

MINCIS, M. and MINCIS, R. Esteatose e esteato-hepatite não alcoólicas. Revista Brasileira de Medicina, 2006, 63, 11, p. 564-570.

MORVAN, E., LIMA, NEA., MACHI, JF., MOSTARDA, C., ANGELIS, K., IRIGOYEN, MC., RODRIGUES, B. and MAIFRINO, LBM. Metabolic, hemodynamic and structural adjustments to low intensity exercise training in a metabolic syndrome model. Cardiovascular Diabetology, 2013, vol. 12, n. 1, p. 1. http://dx.doi. org/10.1186/1475-2840-12-89. PMid:23777435.

MULHALL, BP., ONG, JP. and YOUNOSSI, ZM. Non-alcoholic fatty liver disease: an overview. Journal of Gastroenterology and Hepatology, 2002, vol. 17, n. 11, p. 1136-1143. http://dx.doi. org/10.1046/j.1440-1746.2002.02881.x. PMid:12453271.

PETTINELLI, P., OBREGÓN, AM. and VIDELA, LAI. Molecular mechanisms of steatosis in nonalcoholic fatty liver disease. Nutricion Hospitalaria, 2011, vol. 26, n. 3, p. 441-450. PMid:21892559.

SUZUKI, M., NOMURA, C., ODAKA, H. and IKEDA, H. Effect of an insulin sensitizer, pioglitazone, on hypertension in fructosedrinking rats. Japanese Journal of Pharmacology, 1997, vol. 74, n. 4, p. 297-302. http://dx.doi.org/10.1254/jjp.74.297. PMid:9307325.

Received December 12, 2015 Accepted July 16, 2016 